УДК 78.071.1(450)

ORCID: 0000-0001-7875-2489

Вероніка Псшкова,

аспірант кафедри історії світової музики Національної музичної академї України ім. П. І. Чайковського вул. Архітектора Городецького, 1-3/11, Київ, 02000, Украӥна

Veronika Pieshkova, Postgraduate at the Department of History of World Music, Ukrainian National Tchaikovsky academy of music, 1-3/11 Architect Gorodetsky St., Kyiv 02000, Ukraine

\title{
«ALTRI CANTI D'AMOR TENERO ARCIERO» \\ 3 «ВОСЬМОЇ КНИГИ» МАДРИГАЛІВ КЛАУДІО МОНТЕВЕРДІ: ЦІЛІСНІСТЬ МУЗИЧНОЇ КОМПОЗИЦІї
}

Вперше в українському музикознавстві мадригал «Altri canti d'Amor tenero arciero» представлений з підрядковим перекладом на українську мову. Висвітлюються принципи роботи композитора 3 поетичним текстом та використання музично-риторичних фігур. Конкретизуються характерні риси роботи композитора 3 поетичним текстом у даному мадригалі. Виявляється логіка створення цілісної музичної композиції.

Ключові слова: мадригал, афект, музична риторика, риторична фігура, втілення, Монтеверді, бароко.

«Altri canti d'amor tenero arciero» from the «Eighth Book» of the madrigals Claudio Monteverdi: the integrity of the musical composition. For the first time in the Ukrainian musicology madrigal «Altri canti d'Amor tenero arciero» is represented with interlinear translation into Ukrainian. The principle of the composer's work with poetic text and the use of musical-rhetorical figures is described. Specific features of the composer's work with poetic text in this madrigal are specified. The logic of creating a holistic musical composition is revealed.

Key words: madrigal, affect, musical rhetoric, rhetorical figure, embodiment, Monteverdi, baroque.

«Altri canti d'amor tenero arciero» из «Восьмой книги» мадригалов Клаудио Монтеверди: целостность музыкальной композиции. Впервые в украинском музыковедении мадригал «Altri canti d'Amor tenero arciero» представлен с подстрочным переводом на украинский язык. Освещаются принципы работы композитора с поэтическим текстом и использования музыкально-риторических фигур. Конкретизируются характерные черты работы композитора с поэтическим текстом в данном мадригале. Выявляется логика создания целостной музыкальной композиции. 
Ключевые слова: мадригал, аффект, музыкальная риторика, риторическая фигура, воплощение, Монтеверди, барокко.

Клаудіо Монтеверді був сміливим авангардистом свого часу, чудовим драматургом, який постійно шукав прийоми створення цілісності музичної композиції. Для втілення своїх творчих ідей композитор звертався до прогресивних тенденцій та концепцій свого часу: музичної риторики, теорії афектів.

Проникнення принципів вербальної риторики у музику стало важливим етапом в історії музичного мистецтва. Шлях, на якому з початку музика та риторика наближалися один до одного та в подальшому активно взаємодіяли між собою зафіксований у трактатах епохи Бароко. Праці майстрів (Йоахіма Бурмейстра, Йоганеса Нуциуса, Йоахіма Турінгуса, Афанасія Кірхера, Кристофа Бернхарда, Йогана Маттезона та ін.) сповнені грунтовними знаннями щодо музичної риторики.

У сучасному музикознавчому просторі активно вивчаються барокові праці за допомогою яких стає можливе наближення до розуміння барокової музики в нашому столітті. Серед західноєвропейських праць, що присвячені вивченню становлення та розквіту музичної риторики виокремимо роботи Джованні Маркіоро [15], Джорджа Белоу [13], Донатели Рестані [16], Хуберта Майстера [6], Ельвіо Чіполлоне [14], Дітріха Бартеля [12] та інші. Активно проходять конференції та майстер класи присвячені проблемі музичної риторики. Прикладом можемо назвати засновану 2014 року у пармській консерваторії імені Арріго Бойто (Італія) «LabRetMus» Laboratorio di retorica musicale (лабораторію музичної риторики), де щорічно проходять семінари, майстер класи та концерти присвячені вивченню музичної риторики. Лабораторія представляє собою міждисциплінарний дискусійний простір, що спрямований на привернення уваги аудиторії за допомогою живого прослуховування, широкого використання звукового та аудіовізуального матеріалу, стимулювання обміну та обговорення результатів досліджень.

В слов'янському музикознавстві питання взаємодії мистецтва риторики 3 музичним мистецтвом висвітлюються у працях Марини Лобанової [3], Ольги Захарової [1], Анастасії Мальцевої [7], Сергія Шипа [11], Романа Насонова [8; 9].

Клаудіо Монтеверді - композитор епохи Бароко, тож традиційно, спираючись на естетику епохи, західноєвропейські дослідники звертають увагу на контрасти та наявність музично-риторичних фігур. Проте важливим для розуміння творчий ідей Монтеверді постає виявлення 
музичної цілісності у творчості композитора. Отже аналіз логіки створення такої цілісності є актуальним у сучасному музикознавстві. А в українському музикознавстві питання використання музично-риторичних фігур у творчості італійського композитора XVI-XVII століть Клаудіо Монтеверді не має грунтовних досліджень. У зв’язку з цим, є актуальним звернення до проблеми музичної риторики у вступі до «Восьмої книги» мадригалів «Sinfonia» та першому мадригалі «Книги» «Altri canti d'Amor tenero arciero» («Інші пісні про Амура, ніжний лучник») К. Монтеверді.

Наукова новизна статті полягає в тому, що вперше в українському музикознавстві мадригал «Altri canti d'Amor tenero arciero» представлений 3 підрядковим перекладом на українську мову. Висвітлюється принцип роботи композитора 3 поетичним текстом та використанням музичнориторичних фігур в даному мадригалі.

Mema статті - виявити характерні риси роботи композитора 3 поетичним текстом у мадригалі «Altri canti d'Amor tenero arciero». Завдання статті - аналіз логіки, за якою композитор створював композиційну цілісність мадригалу «Altri canti d'Amor tenero arciero».

Методами дослідження виступають системно-функціональний аналіз (що виявляє характер та спосіб впливу одного елементу музичного твору на інший), поліфонічний та гармонічний аналіз, що тісно пов'язані загалом з аналізом музичної фактури як способу викладення музичного матеріалу. Аналіз грунтується на глибокому вивченні зазначених правил та композиційних вимог епохи Бароко.

«Восьма книга» мадригалів «Guerrieri et amorosi» («Войовничі $\mathrm{i}$ любовні») відкривається інструментальним вступом - Sinfonia. У його інструментальний склад, в книзі під редакцією Франческо Маліпьеро, входять дві скрипки та viola da gamba.

Відповідно до традиції нотного запису XVII століття зафіксована тільки партія basso continuo. Над першим рядком є ремарка «Sinfonia che va inanci al Madrigal che che fegue. Altri canti d'Amor ${ }^{1}-\langle$ Sinfonia, яка йде перед Мадригалом, що слідує після. Altri canti d'Amor».

\footnotetext{
${ }^{1}$ Madrigali guerrieri, et amorosi. Libro ottavo di Clavdio Monteverde. Dedicati alla Sacra Cesarea Maestrà dell'imperator Ferdinando III. In venetia, Appresso Alessandro Vincenti. MDC XXXVIII.
} 


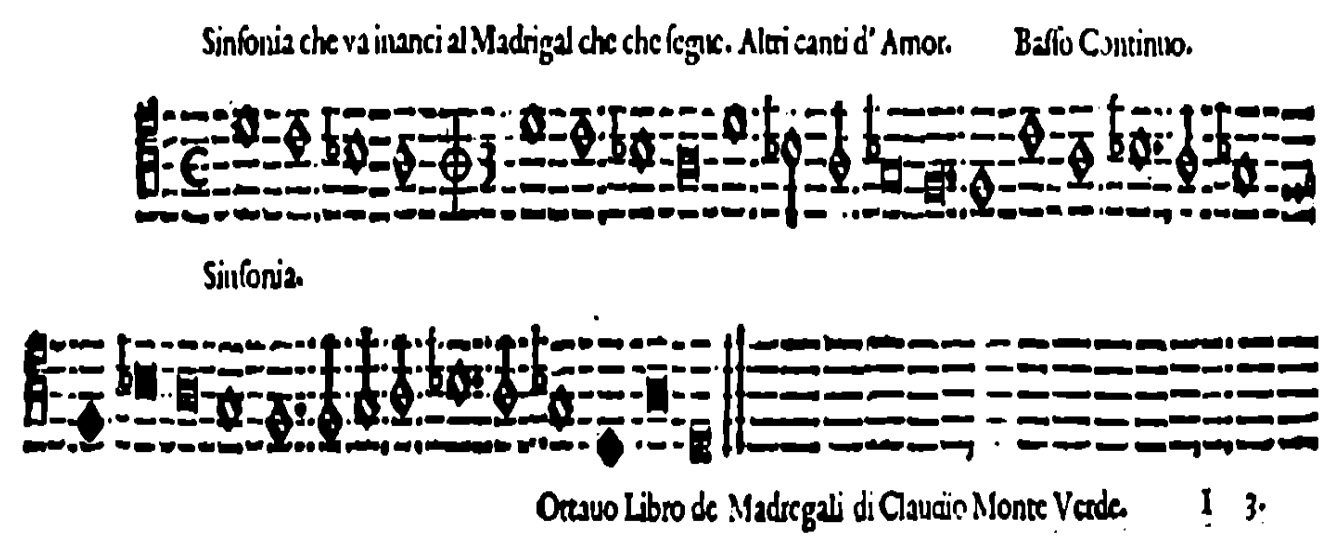

Важливий сам факт наявності вступу до всієї «Книги», що акцентує цілісність задуму циклу мадригалів. У композиторській мадригальній практиці - це рідкість. Наприклад, в мадригальній практиці у Монтеверді Sinfonia присутня тільки в двох «Книгах» мадригалів - в сьомій та восьмій. Sinfonia концентрує основну проблематику «Книги», фіксує головну іiі думку. Вона представляє дві сфери:

- сфера загибелі та поразки;

- сфера життєстверджуюча та переможна.

Sinfonia починається низхідним ходом у Viola da Gamba ${ }^{1}-$ d-c-b-a (проходить двічі), котрий представлений риторичною фігурою catabasis. За цією фігурою затвердилося значення низходження до Аду, спуск [4,5]. Однак в сучасних виданнях можна знайти ще одне значення, актуальне для даного твору - відступлення військ (з прийняттям поразки) [2]. У такому тлумаченні риторичної фігури catabasis міститься усвідомлення завершення життєвого шляху і повне фіаско. Без передмов, Монтеверді відразу представляє одну з образних сфер книги мадригалів - сферу поразки та загибелі.

У basso continuo закладена ще одна (протилежна вищеназваній) риторична фігура - anabasis, що в перекладі означає «піднесення», «рух углиб країни», також може означати тривалий похід військових частин по недружній території. В історичних документах це слово вживається для характеристики успішних військових походів [2].У примітці до праці Ксенофонта «Анабасіс» М. Максимова акцентує увагу на тому, що греки застосовували дієслово ávaßaí - «сходити» не тільки тоді, коли йшлося про підйом на гору, але і коли мався на увазі далекий шлях у напрямку від берега моря вглиб материка [2]. Таким чином, Монтеверді відкриває книгу вельми сильними і контрастними риторичними фігурам, значення яких прояснює вагому проблематику, закладену в книзі.

\footnotetext{
${ }^{1}$ Мадригал у «Книзі» під редакцією Ф. Малип’єро.
} 
Anabasis i catabasis показують два можливих шляхи розвитку образів всієї «Книги». Ці риторичні фігури визначають два вектори руху, які проявляються в поділі книги на дві частини: перша «Войовничі мадригали»; друга - «Любовні мадригали».

Перший мадригал 3 «Восьмий книги» Клаудіо Монтеверді (1638) «Altri canti d'Amor tenero Arciero» («Інші пісні про Амурі, ніжний лучник») належить до войовничих мадригалів. Він слідує за інструментальним вступом і написаний для шести голосів, чотирьох альтів та двох скрипок ${ }^{1}$.

Поетичний текст мадригалу являє собою сонет, автор якого залишається невідомим. Форма сонета $(4+4+3+3)$ визначає i форму мадригалу. Завдяки завершеності за змістом строф, в мадригалі вимальовується дві частини. Перша частина мадригалу - це перші 8 рядків сонета (тт. 1-151), друга частина мадригалу - 6 рядків (тт. 152-246). Кожна 3 частин, в свою чергу, ділиться на розділи, які так само продиктовані структурою сонета. Обидві частини складаються 3 двох розділів: перший розділ грунтується на першій (тт. 1-89) та другий строфах (тт. 90-151), другий розділ - на третій (тт. 152-202) та четвертій строфах (тт. 203-246).

Проаналізувавши смислову наповненість кожної строфи, можемо говорити про наступне:

Перша строфа сонета оповідає про блага, які трапляються, коли Амур оволодіває серцем людини.

Altri canti d'Amor, tenero arciero,

Інші пісні Амура, ніжний лучник

i dolci vezzi, e i sospirati baci;

солодкі пестощі та зітхаючі поцілунки

narri gli sdegni e le bramate paci

промовляєш невдоволення та пристрасно бажаєш спокою

quand'unisce due alme un sol pensiero.

коли з'єднуються дві душі в єдиній думці.

Друга строфа контрастна по відношенню до першої. Місце Амура займає Марс, бог війни, якого славить герой і показує, що войовничі битви він ставить вище, ніж любовні ласки.

Di Marte io canto, furibondo e fiero,

Про Марс я співаю, лютий і гордий,

\footnotetext{
1 За редакцією Ф. Маліп'єро до складу виконавців входять Canto Primo, Canto Secondo, Alto, Tenore Primo, Tenore Secondo, Basso, Violino Primo, Violino Secondo, Viola Alto Primo, Viola da Gamba, Viola Contrabasso, Basso continuo. В факсимиле - Canto Primo, Alto Primo, Alto Secondo, Tenore Primo, Tenore Secondo, Basso Primo, Basso Secondo, Quinto, Basso continuo.
} 
i duri incontri, e le battaglie audaci; жорсткі зустрічі та сміливі битви; strider le spade, e bombeggiar le faci, крокуючі мечі та підривані обличчя

fo nel mio canto bellicoso e fiero.

в моїй пісні войовничій і гордій.

Третя i четверта строфи звернені до Фердинанда ${ }^{1}$. 3 почуттям глибокої поваги оспівується Його імператорська велич.

Tu cui tessuta han di cesareo alloro $\mathrm{O}$, ти, кому вплели царів гідний лавр la corona immortal Marte e Bellona, безсмертна корона Марса і Беллона gradisci il verde ancor novo lavoro, прийми мою прихильно нову працю che mentre guerre canta e guerre suona,

в якій війни співаються і звучать. oh gran Fernando, l'orgoglioso choro $\mathrm{O}$, величний Фердинанд, гордовитий хор del tuo sommo valor canta e ragiona. про високу доблесть твою співає і міркує.

Амур i Марс уособлюють дві емоційні сфери - любовну i войовничу, що відповідає назві книги мадригалів. 3 цього слідує, що Амур і Марс в поетичному тексті показують зіткнення двох контрастних станів душі людини - стану любові і войовничості.

Для втілення в музиці певного стану - афекту народженого поетичним текстом, Монтеверді уважно прочитує сонет. Композитор звертає свою увагу на смислові акценти і кульмінації тексту і підсилює їх вплив на слухача шляхом різних музичних засобів.

Отже, в роботі над текстом мадригалу, композитор використовує такі прийоми музичного прочитання поетичного тексту, які вже використовував у мадригалі «Hor che'l ciel e la terra» [10]:

1. Виразна вимова конкретного слова;

2. Втілення афекту, народженого поетичним рядком;

3. Відображення в музичній тканині мадригалу двох рядків поетичного тексту, які звучать одночасно в різних голосах.

Прикладом першого підходу - втілення композитором афекту слова - $\epsilon$ слова «sospirati» (жадані, зітхаючі), «di Marte» (Марс), «incontri» (зіткнення, зустрічі), «bombeggiar» (підривати) та «gran» (величний).

\footnotetext{
${ }^{1}$ Історичний факт: в 1637 році Фердинанд III став імператором Священної Римської імперії.
} 
Слово «sospirati» (тт. 48-50 canto, тт. 50-54 tenore, тт. 56-58 quinto), яке перекладається як «бажані» «зітхаючі», втілюється за допомогою характерних пауз. Виразні «зітхаючі» паузи поділяють слово на три частини: sospi-ra-ti. Такий поділ представляє значну складність для виконавця. В умовах такого трактування слова композитором, виконавцю необхідно максимально зосередити увагу на вимові цього слова, щоб крізь паузи не втратити стан, закладений в ньому. Для втілення цього слова композитор використовує музично-риторичну фігуру suspiratio. Цю фігуру характеризують саме використання пауз для втілення афекту зітхання.

«Di Marte», що в перекладі означає «Марс» - бог війни, починає другий розділ першої частини мадригалу (тт. 90-151). У поетичному тексті Марс протиставлений Амуру, що дає нам підстави говорити про контраст між любовною та войовничою сферами мадригалу - слово «Di Marte» протилежне попередньому «sospirati», яке безумовно належить до любовної сфери.

Войовничість, яку закладено в характері слова «di Marte», безпосередньо відображена в його ритмічному втіленні. Дуже важлива складова музичного характеру слова - це імітація барабанного дробу, яка утворюється при звучанні слова «di Marte» двічі. Затактова інтонація, що виникає завдяки італійському артиклю «di» (який в даному випадку є невід'ємною частиною слова), сприяє гострому звучанню, сповненому рішучості та відваги.

Слово (враховуючи артикль) поділяється на три склади, а ударним 3 них буде другий: di - Mar - te. Монтеверді використовує ритмічний малюнок, який закладено в природі самого слова i акцентує його в музичному матеріалі. Основа втілення войовничого афекту цього слова міститься більш у ритмічній організації, ніж у мелодичній.

Наступне слово, на яке ми звертаємо увагу - «incontri - «зіткнення» (тт. 102-103 - canto и quinto, 105-106 tenore и basso, 107-108 canto и quinto, 109-110 tenore и tenore II, 110-111 quinto и alto, 113-114 tenore и tenore II). Для втілення афекту композитор використовує фігуру epizeuxsis, якій притаманне повторення слова без перерви, з метою надати йому вагомого значення. Відбувається рух двох партій, які чергуються між собою, утворюючи безперервну послідовність голосів, що рухаються назустріч один одному. Цей прийом повторюється 8 (!) разів та акцентує увагу слухача на музичному втіленні афекту слова «зіткнення».

Слово «bombeggiar» - «підривати» - це перше слово, у втіленні якого беруть участь одночасно всі голоси (тт. 129-130, 141-142). Для досягнення афекту вибуху прийом «ущільнення» звучання $є$ досить органічним і цілком відповідає образу. 
«Bombeggiar» поєднує в собі прийоми втілення двох аналізованих вище слів. Подібно до стрімкого «іncontri», «bombeggiar» виконується пасажами 3 однією ритмічною моделлю, які постійно змінюють свій напрямок: висхідний і низхідний. Тут композитор використовує фігуру tirata (дослівно має переклад - «постріл») для якої характерний гамоподібний діатонічний рух мелодії, що відбувається як правило у швидкому темпі. А власне в ритмічній моделі ми знаходимо схожість зі словом «di Marte». На наш погляд, використовуючи елементи барабанного дробу i пасажного руху, композитор здійснює синтез музичних засобів у слові «bombeggiar», що сприяє повноцінному відтворенню «картини вибуху» і його небезпеки.

Слово «gran» - «величний» (тт. 174-177) - виступає визначенням особистості у фразі «oh gran Fernando» («О, величний Фердинанд»). Втілює це слово впевнений висхідний хід по звуках соль мажорного тризвуку, який охоплює досить широкий діапазон (дуодеціми). Найвища точка такого підйому доводиться на звук $d$, який займає в цій фразі провідну позицію та власне озвучує слово «gran». Схвильовано-піднесений вигук є ознакою фігури exclamatio, яка утворює кульмінацію мадригалу.

Для оспівування величі Фердинанда Клаудіо Монтеверді відходить від переважаючого до цього моменту багатоголосся. Виконання цілого розділу (тт. 152-202) композитор доручає солюючому басу в інструментальному супроводі. Бас, ніби уособлює голос людини, який приносить свою благословенну пісню великому Фердинанду.

У роботі над втіленням афекту, народженого цілим поетичним рядком, показовим виступає рядок «quand'unisce due alme un sol pensiero» (коли з'єднуються дві душі в єдиній думці) (тт. 78-89). Ця фраза знаходиться на межі двох розділів першої частини. Дуже тонко Монтеверді прочитує цю фразу: рух мадригалу сповільнюється і три голоси (canto, quinto, tenore) поступово зливаються в один звук «ре», розкриваючи значення слів «в єдиній думці». Монтеверді втілив з'єднання двох душ, про які говорить поет i, у такий спосіб, наблизив слухача до розуміння єдності музичного і поетичного текстів.

Характерною стильовою рисою Монтеверді стає третій принцип відтворення афекту, коли він об'єднує два рядки поетичного тексту, що звучать одночасно в різних голосах. У фразі «е bombeggiar le faci» (підривати зірки) і «fo nel mio canto bellicoso e fiero» (в моїй пісні войовничій та гордій) (тт. 136-138) музичний розвиток здійснюється парами голосів: canto и quinto - озвучують фразу «e bombeggiar le faci»; tenore II i basso - «fo nel mio canto bellicoso e fiero»; alto - «fo nel mio canto bellicoso e fiero» i tenore - «e 
bombeggiar le faci». Головним засобом втілення афекту тут виступає одночасне звучання різних поетичних текстів у партіях alto i tenore.

Кожна партія передає афект, закладений у поетичному тексті. У фразі, де мова йде про войовничі та горді пісні - афект рішучості (alto) - композитор використовує рух на одному звуці з поступовим дробленням тривалостей, що асоціюється 3 барабанним дробом. А ось «вибухи» композитор втілює стрибками на широкі інтервали 3 подальшими «злітаючими» пасажами, підкреслюючи силу руйнування. Подібне возз'єднання поетичних рядків сприяє затвердженню войовничої сфери в мадригалі.

Таким чином, для Клаудіо Монтеверді стає показовим принцип відбору в тексті саме тих слів та фраз які грають ключову роль у розкритті змісту поетичного тексту та максимальне підсилення їх значення в музичній композиції. В основному, композитор бере всі необхідні якості для втілення 3 самого слова: ритм (акцентує склади) та мелодичну спрямованість (яка відповідає змісту слова). Такий принцип роботи 3 текстом був основою саме вербальної риторики, в якій для підсилення впливу на слухача обиралися та підкреслювалися найвагоміші слова.

У мадригалі Клаудіо Монтеверді «Altri canti d'Amor tenero arciero» композитор користується трьома головними принципами досягнення цілісності музичної композиції. Вони проявляються у виразному музичному прочитанні конкретного слова, цілого поетичного рядка та поєднанні в єдиному звучанні двох поетичних рядків кожен з яких лунає в окремому голосі.

1. Захарова О. Риторика и западноевропейская музыка XVII-первой половинь ХVIII века: принщипь, приемы. Москва : Музыка, 1983. 79 с.

2. Ксенофонт. Анабасис//Историки Грещии/пер. С. Омерова, сост. и ред. Т. А. Миллер, примеч. М. Л. Гаспарова и Т. А. Миллер. Москва : Художественная литература, 1976. 432 c.

3. Лобанова М. Западноевропейское музыкальное барокко: проблемы эстетики и поэтики. Москва : Музыка, 1994. 320 с.

4. Латинско-русский словарь. Дворецкий И. Х. 2-е изд., перераб. и доп. Москва: Радуга, 1976. 1096 c.

5. Латинско-русский и русско-латинский словарь/сост. А. В. Подосинов, Г. Г. Козлова, А. А. Глухов, А. М. Белов ; под общ. ред. А. В. Подосинова. Москва : Наука, 2004. 744 с.

6. Майстер Х. Музыкальная риторика: ключ $к$ интерпретачии произведений И. С. Баха. Москва : Классика-ХХІ, 2013. 112 с.

7. Мальцева А. Музыкально-риторические фигуры барокко: проблемы методологии анализа (на материале лютеранских магнификатов XVII века) : дисс. ... канд. искусствоведения. 17.00.02 - Музыкальное искусство. Новосибирск, 2013. 340 с.

8. Насонов Р. А. Музыкальная риторика Афанасия Кирхера: к истории «готовых слов»//Музыкальная наука на постсоветском пространстве: материаль междунар. интернет-конференции. Москва: PAM им. Гнесиных, 2010. URL: 
http://2010.gnesinstudy.ru/wp-content/uploads/2010/03/Nasonov.pdf (дата обращения: 05.02.2018).

9. Насонов Р. Музькальная риторика Иоганна Иоахима Кванияа // Naиchnyy vestnik Moskovskoy konservatorii. Москва, 2013. № 1. C. 162-168.

10. Пєшкова В. Мадригал К. Монтеверди «Hor che'l ciel e la terra» («Час, когда небо и земля»): особенности воплощения поэтического текста. Київське музикознавство. Kuїв, 2016. Bun. 54. C. 79-85.

11. Шип С. Методологическое значение доктрины о музыкальной риторике в немецком и украинском музыкознании//Київське музикознавство Київ-Dusseldorf, 2011. Bun. 37. C. 23-49.

12. Bartel D. Musica Poetica: Musical-Rhetorical Figures in German Baroque Music: University of Nebraska Press, 1997. 471 p.

13. Buelow G. J. Music and Rhetoric in The New Grove Dictionary of Music and Musicians, ed. Stanley Sadie, vol. 15, 1980. P. 793-803.

14. Cipollone E. Musica rhetoricans. Fra figure di Sciarrino, Unités Sémiotiques Temporelles e Figurenlehren barocche. Tesi di laurea in filosofia. Sessione I. Anno accademico 2005-2006. URL: http://elvio.cipollone.free.fr/papers/MusicaRhetoricans.pdf (дата звернення 01.02.2018).

15. Marchioro G. La musica dell'anima. Libreria universitaria edizioni, Limena (PD). 2016, 174 p.

16. Restani D. Musica e retorica tra Grecia e Roma. URL: http://www.oilproject.org/lezione/musicae-retorica-tra-grecia-e-roma-20116.html (дата звернення 16.02.2018).

17. Solci $R$. La retorica musicale e le sue architetture simboliche ed espressive. Corso di: Analisi dei repertori - modulo compositivo (Triennio) PARTE V. URL: http://websolci.altervista.org/attachments/article/13/ADR-Parte-05-a

La\%20Retorica\%20musicale.pdf (дата звернення 30.10.2017).

\section{References}

1. Zakharova, O. (1983). Rhetoric and western European music XVII - the first half of the XVIII century: principles, techniques. Moscow, Muzyka. 78 p. [in Russian].

2. Xenophon. (1983). Anabasis. (S. Osherova, Trans.) Moscow, Khudozhestvennaya literatura. 432 p. [in Russian].

3. Lobanova, M. (1994). Western European musical baroque: problems of aesthetics and poetics. Moscow, Muzyka. 320 p. [in Russian].

4. Latin-Russian Dictionary, (1976). Dvoretsky I. H. Moscow, Raduga. 1096 p. [in Russian].

5. Latin-Russian and Russian-Latin dictionary, (2004). A. V. Podosinov, G. G. Kozlova, A. A. Glukhov, A. M. Belov. Moscow, Nauka. 744 p. [in Russian].

6. Meister, H. (2013). Musical rhetoric: the key to the interpretation of the works of J. S. Bach. Moscow, Klassika-XXI. 112 p. [in Russian].

7. Maltseva, A. (2013). Musical-rhetorical figures of the baroque: problems of the methodology of analysis (based on the material of the lutheran magnificates of the 17th century). Candidate's thesis. Novosibirsk, Muzykal'noye iskusstvo. 340 p. [in Russian].

8. Nasonov, R. A. (2010). The musical rhetoric of Athanasius Kircher: to the history of «readymade words». Moscow, RAM im. Gnessin. Available at: http://2010.gnesinstudy.ru/wpcontent/uploads/2010/03/Nasonov.pdf. [Accessed 05.02.2018].

9. Nasonov, R. (2013). Musical rhetoric of Johann Joachim Kwantz. Nauchnyy vestnik Moskovskoy konservatorii. Moscow. pp. 162-168 [in Russian]. 
10. Pieshkova, V. (2016). Madrigal K. Monteverdi «Hor-che'l ciel e la terra» («The time when heaven and earth»): features of the embodiment of the poetic text. Kyyivs'ke muzykoznavstvo 56, pp. 79-85 [in Russian].

11. Schip, S. (2011). Methodological significance of the doctrine of musical rhetoric in german and ukrainian musicology. Kyyivs'ke muzykoznavstvo 37. pp. 23-49 [in Russian].

12. Bartel, D. (1997). Musica Poetica: Musical-Rhetorical Figures in German Baroque Music. University of Nebraska Press. 471 p. [in English].

13. Buelow, G. J. (1980). Music and Rhetoric in The new Grove dictionary of music and musicians 15. pp. 793-803 [in English].

14. Cipollone E. (2006). Rhetoricians music. Among the figures of Sciarrino, Unités Sémiotiques Temporelles and Baroque Figurenlehren. Anno accademico. Available at: http://elvio.cipollone.free.fr/papers/MusicaRhetoricans.pdf [in Italian] [Accessed 01.02.2018].

15. Marchioro, G. (2016). The music of the soul. Libreria universitaria edizioni, Limena (PD). 174 p. [in Italian].

16. Restani,D. Music and rhetoric between Greece and Rome. Available at: http://www.oilproject.org/lezione/musica-e-retorica-tra-grecia-e-roma-20116.html [in Italian] [Accessed 16.02.2018].

17. Solci, R. Musical rhetoric and its symbolic and expressive architectures. Available at: http://websolci.altervista.org/attachments/article/13/ADR-Parte-05-a

La\%20Retorica\%20musicale.pdf [Accessed 30.10.2017]. 